\title{
Senior cohousing in the context of an ageing society*
}

\section{Małgorzata Kampka}

\begin{abstract}
The demographic changes of the $21^{\text {st }}$ century, especially all aspects of ageing, require discussion about the needs of an ageing society which should lead to the development of urban and architectural solutions for older people, based on examples of senior cohousing. The ageing process should be taken into account because it affects older people on many levels and influences their functioning in a society. The aim of this paper is to obtain answers to the research questions concerning architectural elements and urban planning of senior cohousing. What is more, it is important to assess whether this type of development is a good response to the demographic processes of the $21^{\text {st }}$ century. In addition, the goal is to indicate the differences between cohousing dedicated to seniors in Poland and abroad.

The multidimensional research methodology (case studies, literature analysis and comparative studies) helps to select a solution which meets the challenges of contemporary demography: cohousing. The fundamental premise of this idea is to live in a community and to keep the sense of privacy. In the case studies, attention was paid to several guidelines such as location, the average age of inhabitants, participation in the planning process, access to medical care and various facilities offered by the community.

The potential of buildings dedicated to the elderly is widespread around the world, while in Poland it remains untapped. Senior cohousing makes the ageing process easier for people, it helps them to overcome difficulties and improve their situation. To sum up, staying in the community encourages inhabitants to share experiences, emotions, problems, spend spare time surrounded by friends and build valuable relationships. This type of building should be treated as an alternative to old people's and nursing homes. The adopted senior housing solutions will affect both present and future generations.
\end{abstract}

Keywords: senior cohousing, ageing, community

\section{Introduction}

The ageing process is an integral part of human life. It has also become an increasingly serious challenge for architects and urban planners. According to a scientific definition in the encyclopaedia of Polish Scientific Publishers PWN [Wydawnictwo Naukowe PWN], ageing is a long-term biological process, which is based on changes occurring over time, is associated with a weakening of regulatory functions of the nervous, visual and motor systems, which leads to a reduction in muscle strength, eyesight problems, the speed of conduction of nerve impulses and memory disorders. [....] Old age is conventionally considered to begin at 60 to 65 years of age when this process clearly intensifies1. This definition illustrates the problems that older people start struggling with over the age of 60 . Taking into account the aspects indicated above, it is necessary to look at the issue of construction for seniors in the context of changes affecting older people. The architecture dedicated to seniors should not only make their life easier but also help them enjoy their optimal mobility and create a sense of belonging to a group for as long as possible.

\footnotetext{
* The article is based on the author's MA thesis, written under the supervision of dr inż. arch. Katarzyna Mazur-Belzyt at the Faculty of Architecture of the Silesian University of Technology in Gliwice, 2017.

${ }^{1}$ http://encyklopedia.pwn.pl/haslo/starzenie-sie;3979189.html (accessed on 19.06.2018).
} 
A lengthening of people's lifespan makes the "silver economy"2 an important element of deliberations among representatives of local governments, developers and designers. In the 1980s and 1990s, Western European and North American countries were trying to meet the growing needs of the oldest generation by providing them with different options to choose from - towns and housing estates for seniors, intergenerational houses, tenant mixes, multigenerational and senior cohousing. Senior cohousing, a construction type mentioned in the title, is a forward-looking area of research. However, it is still a niche in the Polish construction industry dedicated to people over 60 . The issue of demographic processes resulting in the ageing of the population leads to the following research questions:

- What are the consequences of the ageing process for people?

- Can cohousing be the right answer to modern demographical processes?

- What is the genesis and typology of cohousing?

- What is the difference between construction dedicated to seniors in Poland and abroad?

The aim of this article is to obtain answers to the research questions, as well as to compare the selected existing examples of buildings dedicated to people aged 60+. For this purpose, the following research methods were used: ${ }^{3}$

- case study - finding a typology of function and form, multiple comparative and descriptive studies;

- descriptive analysis of various selected features of the researched problem;

- participation in workshops. ${ }^{4}$

On the other hand, the utilised research techniques were:

- analysis of existing literature - e.g. research conducted in a given field so far;

- comparative theory employed in comparisons of multiple case studies presented as comparative tables, the creation of a typology of solutions, indication of similarities and oppositions.

\section{Contemporary demographic processes}

The ageing process is a new phenomenon that emerged after the "demographic explosion" observed in the middle of the 20th century. It is connected to the end of the Second World War, the improvement of the quality of life and the development of medicine, mainly in developing countries. This resulted in a decrease in the mortality rate of the oldest

\footnotetext{
${ }^{2}$ Silver Economy - it is a system of services and sales of goods that use the potential of seniors, facilitating their daily life, rehabilitation and meeting the needs related to care and recreation,. source: http://kigs.org.pl/projekty/gospodarka-senioralna/ (accessed on 19.06.2018).

${ }^{3}$ E. Niezabitowska, 2014, Metody i techniki badawcze w architekturze, Wydawnictwo Politechniki Śląskiej, Gliwice, p. 182

${ }^{4}$ International workshops related to the genderSTE project entitled "Gender in Research and Application in Projects: special focus on intersectionality (age, race, etc.)" took place at the Faculty of Architecture of the Silesian University of Technology in Gliwice on 4-5.07.2016; http://www.lab60plus.pl/organizowane-wydarzenia/genderste (accessed on 22.06.2018).
} 
generations and an increase in life expectancy. The ageing of the society has become a global phenomenon. According to data [Błędowski 2012, p. 20], the highest percentage of older people (aged 65+) resides in Europe.

Forecasts for 2030 predict the largest increase in the number of people aged 65-74 - they will amount to about $24.3 \%$ of the total European population. At the same time $7.1 \%$ of the Europeans will reach or exceed the age of 80 (Table 1). Of all the analysed regions, Europe achieves the highest score in the growth of people of post-working age. ${ }^{5}$

Table 1. Development of the population aged 65+ and forecast for 2030 in selected regions of the world

\begin{tabular}{|l|l|c|c|c|}
\hline \multirow{4}{*}{ Region } & Year & $\begin{array}{c}65-74 \text { years } \\
{[\%]}\end{array}$ & $\begin{array}{c}75-79 \text { years } \\
{[\%]}\end{array}$ & $\begin{array}{c}80 \text { years and older } \\
{[\%]}\end{array}$ \\
\hline \multirow{4}{*}{ Europe } & 2000 & 15.5 & 6.6 & 3.3. \\
\cline { 2 - 5 } & 2015 & 18.7 & 8.8 & 5.2 \\
\cline { 2 - 5 } & 2030 & 24.3 & 11.8 & 7.1 \\
\hline \multirow{5}{*}{ North America } & 2000 & 12.6 & 6.0 & 3.3 \\
\hline & 2015 & 14.9 & 6.4 & 3.9 \\
\cline { 2 - 5 } & 2030 & 20.3 & 9.4 & 5.4 \\
\hline \multirow{5}{*}{ The Middle East and North Africa } & 2000 & 6.0 & 1.9 & 0.8 \\
\cline { 2 - 5 } & 2015 & 7.8 & 2.8 & 1.4 \\
\cline { 2 - 5 } & 2030 & 12.0 & 4.6 & 2.2 \\
\cline { 2 - 5 } & 2000 & 4.3 & 1.4 & 0.6 \\
\cline { 2 - 5 } & 2030 & 8.1 & 1.9 & 0.9 \\
\hline
\end{tabular}

Source: own elaboration based on: P. Błędowski P. et al., 2012, Raport na temat sytuacji osób starszych w Polsce, Instytut Pracy i Spraw Socjalnych, Warszawa, p. 20

According to the statistical data of the Central Statistical Office GUS6 [Główny Urząd Statystyczny], the population of Poland in 2014 was 38484 thousand people. 2014 was the third consecutive year during which a population decline was recorded. This was largely influenced by birth and death rates and migrations. Moreover, since the beginning of the 1990s, a decrease in the human mortality rate has also been observed. Studies carried out by the Central Statistical Office (GUS) in 2013 showed a significant prevalence of women among the elderly. The average life expectancy for women was 81.1 years, while for men it was 73.1

\footnotetext{
${ }^{5}$ P. Błędowski et al., 2012, Raport na temat sytuacji osób starszych w Polsce, Instytut Pracy i Spraw Socjalnych, Warszawa, p. 20.

${ }^{6}$ Główny Urząd Statystyczny, 2015, Podstawowe informacje o rozwoju demograficznym Polski do 2014 roku, Warszawa (available on the internet: http://stat.gov.pl/obszary-tematyczne/ludnosc/ludnosc/podstawowe-informacje-o-rozwojudemograficznym-polski-do-2014-roku,12,5.html) (accessed on 24.06.2018).
} 
years (Fig. 1). Since the beginning of the 1990s, the life expectancy has increased by 6 years for women and by 7 years for men. The following factors are responsible for this increase: the trend of leading a healthy lifestyle, the use of modern methods in medicine and the increase in Poles' awareness of with the risks of falling into addictions and contracting civilizational diseases.

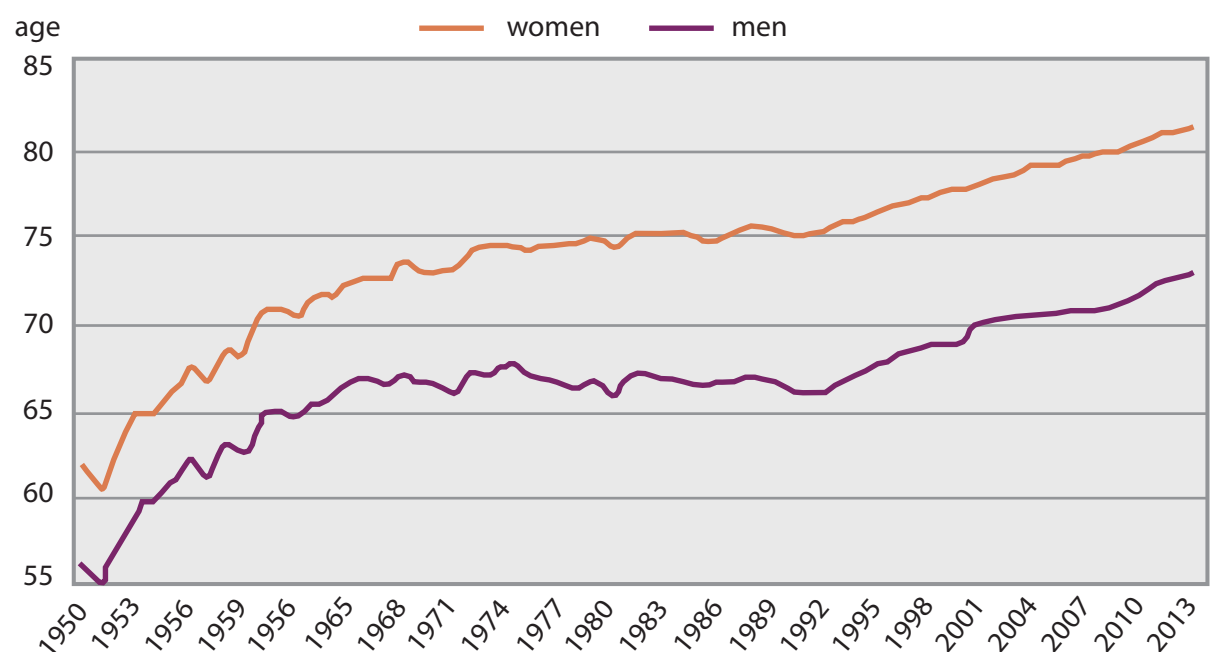

Fig. 1. Average life expectancy for men and women in Poland in 1950-2013

Source: own elaboration based on: Główny Urząd Statystyczny, 2015,

Podstawowe informacje o rozwoju demograficznym Polski do 2014 roku, Warszawa, p. 13

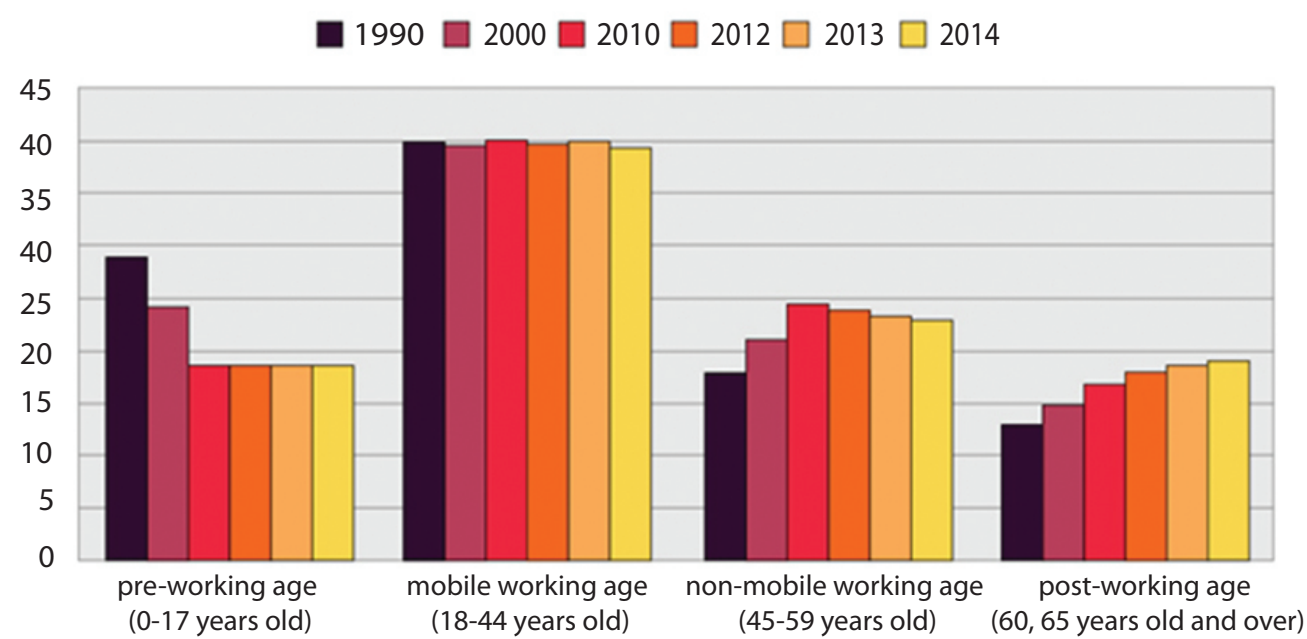

Fig. 2. Poland's population according to economic age groups (in \%) in 1990-2014

Source: own elaboration based on: Główny Urząd Statystyczny, 2015,

Podstawowe informacje o rozwoju demograficznym Polski do 2014 roku, Warszawa, p. 13 
The graph (Fig. 2.) presents an illustration of the population according to economic age groups. The decreasing number of people of pre-working age is a noticeable aspect, which translates into a lower (negative) birth rate. The number of people of post-working age (60, 65 and over) increases on a year by year basis - in 2014 they accounted for nearly $20 \%$ of the total population.

The ageing of the Polish population is one of the major demographic problems in the current development phase. Forecasts for subsequent years until 2050 are a clear indication of further changes in the same direction. ${ }^{7}$ The figures that are particularly noteworthy are the increasing percentage of people in post-working age, the change in the life expectancy limit and the increasing prevalence of women among the elderly due to the higher mortality rate of men. These changes must entail an interdisciplinary approach to modern construction and an appropriate adaptation of the built environment to the needs of the elderly, as well as to the needs of future generations.

\section{Consequences of the ageing process}

The ageing process is composed of three different aspects: physiological, psychological and sociological. They may supersede each other, resulting from the preceding stages, or appear at the same time with bigger or smaller intensity: ${ }^{8}$

\section{(a) physiological and biological effects of old age}

The main effects of this stage are problems with the immune system, muscle atrophy, skin ageing, weakening of organ functions. Problems with eyesight, sense of smell or taste increase the feeling of helplessness, exclusion and infirmity to the same extent as problems with movement do;

\section{(b) emotional and mental effects of old age}

changes in the psyche of an older person influence personality and mental fitness. The ageing entails many different types of stress related to e.g. retirement, loss of a partner, change of place of residence. All these factors may lead to depression, social isolation, lack of self-acceptance. Cognitive changes pertain to a lengthening of response time to stimuli, problems with concentration and memory, difficulties with orientation in space; ${ }^{9}$

\section{(c) sociological effects of old age}

Awareness of the limitations of the ageing process becomes a huge obstacle to establishing or maintaining social contacts. Lack of understanding within a family, isolation in one's own place of residence or staying in a nursing home against one's will are just some of the factors excluding seniors from becoming socially active and from taking actions for common development.

\footnotetext{
7 Główny Urząd Statystyczny, 2014, Prognoza ludności na lata 2014-2050, Warszawa, p. 77.

8 R. Petyniak, 2015, Uniwersytet Trzeciego Wieku, instytucją edukacyjna i wspierająca osoby w starszym wieku. Na przykładzie opinii uczestników Uniwersytetu Trzeciego Wieku przy Uniwersytecie Rzeszowskim. Praca magisterska. Uniwersytet Rzeszowski, Wydział Pedagogiczny, Rzeszów, p. 16-25.

9 I. Benek, A. Szewczenko, 2015, Ergonomia w projektowaniu obiektów z funkcją opieki dla osób starszych, Wydział Architektury, Zeszyty Naukowe Małopolskiej Wyższej Szkoły Ekonomicznej w Tarnowie, 27, 2-3, p. 81-82.
} 
The ageing process is a challenge not only for seniors, but also for the people whose task is to optimise space to meet the specific needs of older people. The growing percentage of seniors in the general population cause the people aged 60+ (people born in 1946-1964

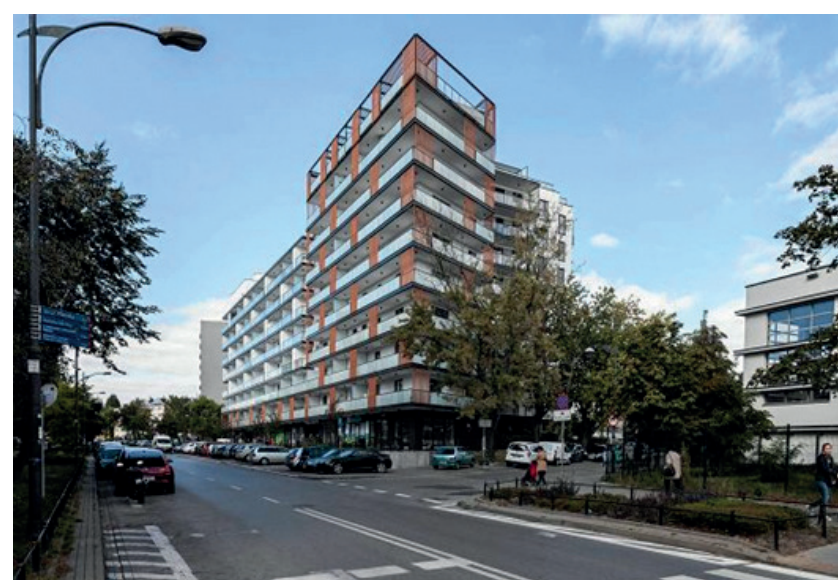

Fig. 3. The building housing the Model Senior Residence (WMS) fully adapted to the needs of people with disabilities

Source: http://warszawa.wyborcza.pl/warszawa/51,34862,20751142.html?i=3 (accessed on 24.08.2018)

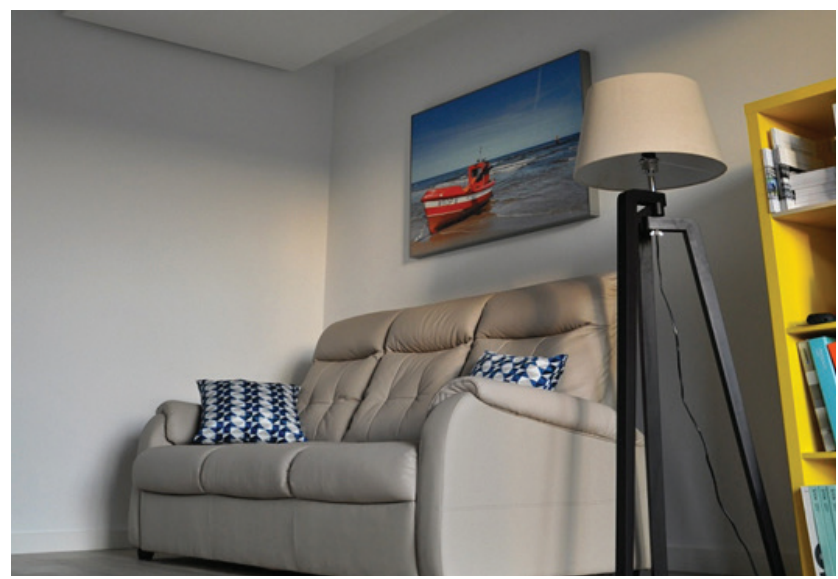

Fig. 4. WMS Interior furnished to meet the needs of older people Source: http://warszawa.wyborcza.pl/warszawa/51,34862,20751142.html?i=3 (accessed on 24.08.2018) - the post-war generation of seniors, often called "baby boomers", who base their hierarchy of values on the traditional division of roles in the family $)^{10}$ to become the main recipients of modern solutions in the housing industry. The concept of "ageing in place" assumes that older people can choose their place of residence. It is to be a place where one will live for as long as possible and will also have access to medical services. One of the projects implementing the above notions is the Model Senior Residence ([Wzorcowe Mieszkanie Seniora] WMS) ${ }^{11}$ in Warsaw. The project assumed carrying out an exemplary adaptation of an apartment to the needs of an older person using a wheelchair. The aim of the project was to implement the idea of "ageing in place" and to utilise a modern supporting technology (Figs 3 and 4).

\footnotetext{
${ }^{10}$ http://mateuszgrzesiak.natemat.pl/122459,21-roznic-pokoleniowych-miedzy-baby-boomers-x-i-y (accessed on 19.06.2018).

11 The Model Senior Residence (WMS) at 2 Wrzeciono Street in Warsaw was completed in September 2016. The coordinator of the project was arch. Agnieszka Cieśla, PhD, Eng.; http://sarp.warszawa.pl/wordpress/wp-content/uploads/2015/11/opis-WMS.pdf (accessed on 27.06.2018).
} 


\section{Senior cohousing}

The forms and ways of living of people of different ages and needs, which have been developing over the years, have led to the initiation of the idea of cohousing. The concept is based on the residents themselves, who participate in the process of creating and making decisions. According to Durrett, cohousing (etymology: "community" and "housing") is a form of housing that functions according to certain rules, is accompanied by additional functions supporting integration, like spending time together, sharing experiences and skills and enjoying interpersonal contacts. Cohousing buildings can take different forms - from compact city blocks located within an urban fabric to individual blocks of flats or detached houses freely scattered on a plot of land in suburban or rural areas ${ }^{12}$ (Fig. 5).

Despite the diversity of forms, two principles should be realized: theintegration of residents and, at the same time, respect for their privacy. Zoning is also a binding determinant - each housing unit has access to the public area through its semi-private space (a terrace, veranda or patio), which is a buffer between the zones. ${ }^{13}$ Green areas, paths and meeting places are not the only common areas available. A community house and a common house are where functions available to all residents are located, e.g. a laundry room, a workshop, guest rooms and a medical care room. The community house is the central point of

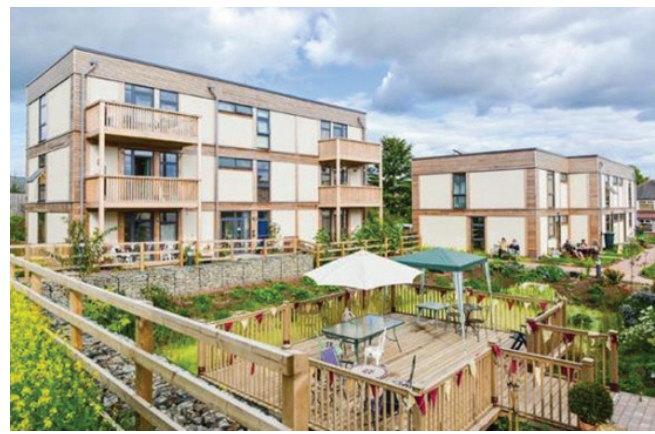

Fig. 5. LILAC (West Leeds, UK) - ecological cohousing with twenty flats consisting of detached blocks of flats and a community house

Source: http://www.modcell.com/projects/lilac-affordableecological-co-housing/ (accessed on 25.08.2018) the whole project - it houses a large dining room, where everyone gathers for common meals and, next to it, a kitchen for cooking and preparations. The community oversees the division of tasks which are completed by "task groups", manages the entire estate and collects contributions for current expenses.

Senior cohousing originated in Denmark. An event that had a direct impact on the development of this type of housing took place in 1979 when the Danish government set up a senior citizens' advisory committee. Its goal was to improve the quality of senior policy and the housing conditions of older people. The rapidly growing wave of change in people's beliefs transformed into a binding policy in 1997 and national organisations aiming to support senior citizens started to form. In 1982 two Danes, Tove Duva and Lissy Lund Hansen, launched a campaign to focus attention on the independence of senior citizens' homes. The idea they presented included a plan following the cohousing guidelines. It was carried out

\footnotetext{
${ }^{12}$ Ch. Durrett , 2009, The Senior Cohousing Handbook. A Community Approach to Independent Living, New Society Publishers, p. 19.

${ }^{13}$ Ibidem, p. 11
} 


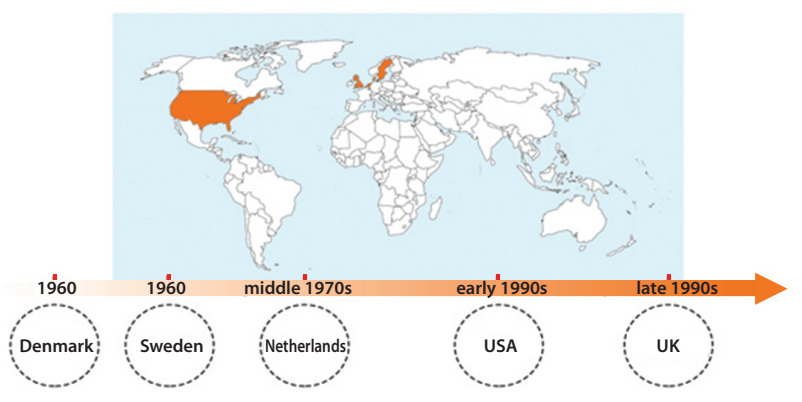

Fig. 6. Time axis - history of cohousing

Source: own elaboration based on: https://www. towergateinsurance.co.uk/commercial-property-insurance/iscohousing-the-future (accessed on 24.08.2018), map: http://www.coloringpagebook.com/world-map-coloringpage/ (accessed on 24.08.2018)

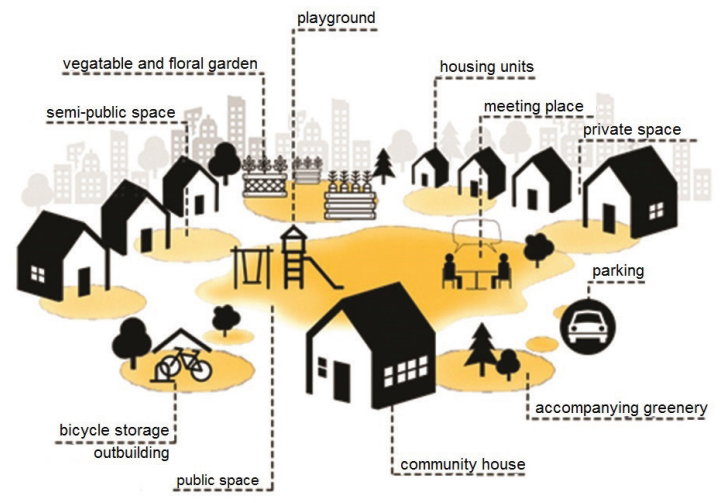

Fig. 7. Cohousing layout plan

Source: own elaboration based on:

http://cohousing.org.uk/what-cohousing (accessed on 21.08.2018) by a housing developer named Lejerbo. Thus the world's first senior cohousing was created in 1987- Midgården. In 1995 another landmark event took place Henry Nielsen developed a model for creating senior cohousing communities. This entailed the development of a detailed code of conduct that is based on a participatory process.

Cohousing can be divide into two categories: intergenerational and senior. This is a division according to the age of the community's inhabitants. Both categories introduce their own individual features related to the specific needs of a given community (Figs 6 and 7).

\section{Examples of good practices from around the world and from Poland}

\section{Glacier Circle, California}

A noteworthy example is located in California (USA) and is the first senior cohousing in America. It is called Glacier Circle. ${ }^{14}$ It was created in 2006 as a result of cooperation of architects (Julie Haney, Macaulay + Architects), a developer (Muir Commons) and a project advisor (Virginia Thigpen).

\footnotetext{
${ }^{14}$ Prepared on the basis of: Ch. Durrett, 2009, The Senior Cohousing Handbook. A Community Approach to Independent Living, New Society Publishers, p. 203-205.
} 
A group of people, who felt lonely and overwhelmed by problems of the ageing process and by their household duties, organized the first meeting of future residents in March 2002. The project was established in the vicinity of greenery and a pond. Its great advantage was the proximity to public transport and shops. The average age of the inhabitants is approximately 80: retired people aged 74-92, most of whom have known each other for 40-50 years from interest circles or church communities. There are eight detached, single- and two-storey

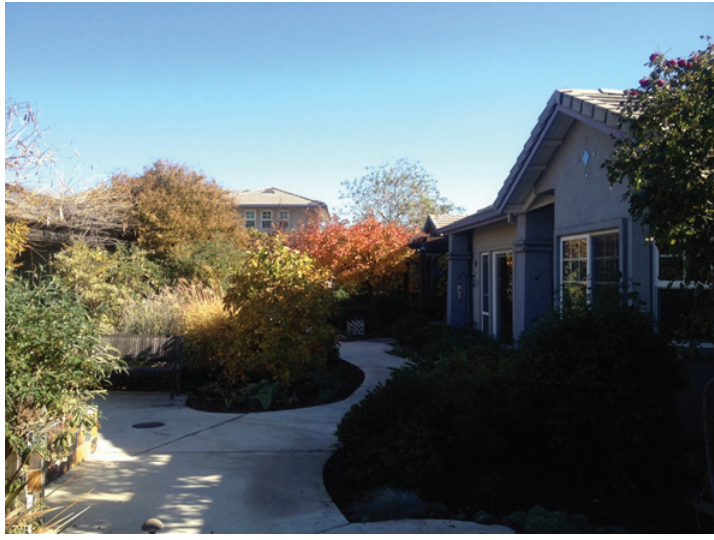

Fig. 8. View of the common courtyard - Glacier Circle Community in Davis, California

Source: ttps://cohoto.net/ahaaa/72 (accessed on 24.08.2018) residential units (the floor layout of the flats allows for separate bedrooms for caretakers). A community house is a separate building which is located on the way from a car park to the individual apartments. Flowing paths surrounded by blossoming greenery run around a common courtyard which is also visible from all the apartments. The buildings are equipped with photovoltaic panels and solar water heating systems, while the residents enjoy using the ecological garden. Weekly 2-hour meetings in the community house followed by joint trips to restaurants are an important part of the community's functioning. The project is financed from the rental of flats and additional apartments. All residents have to participate in a common budget related to current expenses (Fig. 8).

\section{Older Women's Cohousing, London}

Another foreign example has an unusual structure. Older Women's Cohousing $(\mathrm{OWCH})^{15}$ is located in London (UK). It is the first senior cohousing in the UK for women only (an experimental project). It was built in 2016 (Fig. 9).

Madeleine Levius was the main initiator of this project. Later, cooperation with the Housing for Women community was established.

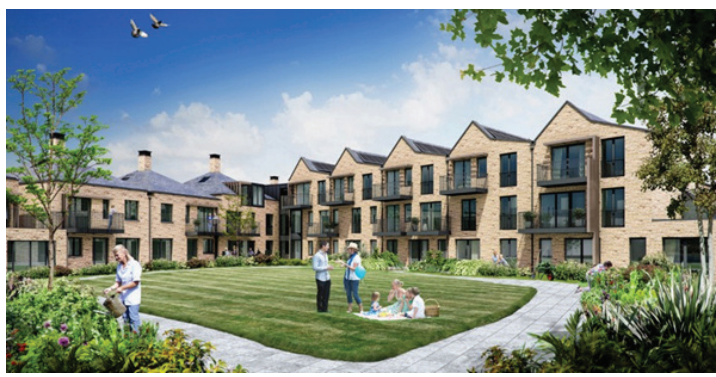

Fig. 9. Older Women's Cohousing - a view of the common space (visualization)

Source: https://hdawards.org/archive/2016/winning schemes/happi_winner/womens_cohousing.php php (accessed on 24.08.2018)

\footnotetext{
${ }^{15}$ Prepared on the basis of: M. Brenton, 2013, Senior Cohousing Communities - an Alternative Approach for the UK?, JRF Programme Paper A Better Life, Joseph, Rowntree Foundation, Wielka Brytania (available on the internet: https:// www.jrf.org.uk/sites/default/files/jrf/migrated/files/senior-cohousing-communities-full.pdf) (accessed on 21.08.2018).
} 
Maria Brenton became the manager of the whole process. After meetings of participating women had taken place, the group was joined by architects from the Pollard Thomas Edwards design office. From that moment on they started working together on projects of residential buildings and spatial development. Decisions concerning meeting requests and adapting the space to specific needs were made by consensus. The project was awarded the Richard Feilden Award at the 2016 Housing Design Awards competition for the best residential project. The whole investment process lasted 15 years. The residents are a group of about 20 single women $50+(50-80$ years old). The plot used for the project is located in the northern part of London near the city centre within the compact urban fabric. It is surrounded by greenery and service and recreation areas. The three-storey buildings resemble the shape of the letter " $\mathrm{L}$ ", in the form of a single building forming a compact city block. The building houses 25 flats of various sizes, both proprietary and social. An open and flexible apartment layout plan allows for a temporary room for a caretaker to be established. The rules in force in this cohousing apply to various areas of life, among others: the residents share cars due to a small car park, each member should pay contributions and engage in meetings and "task forces", conflicts are resolved by an invited mediator or a psychologist "from outside".

\section{Senior citizens' housing estate - Stargard Szczeciński}

Senior citizens' housing estate in Stargard Szczeciński (West Pomerania Province) is a Polish example of housing for the older people. ${ }^{16}$ It is not an example of cohousing, but rather a cluster of assisted living buildings (Fig. 10).

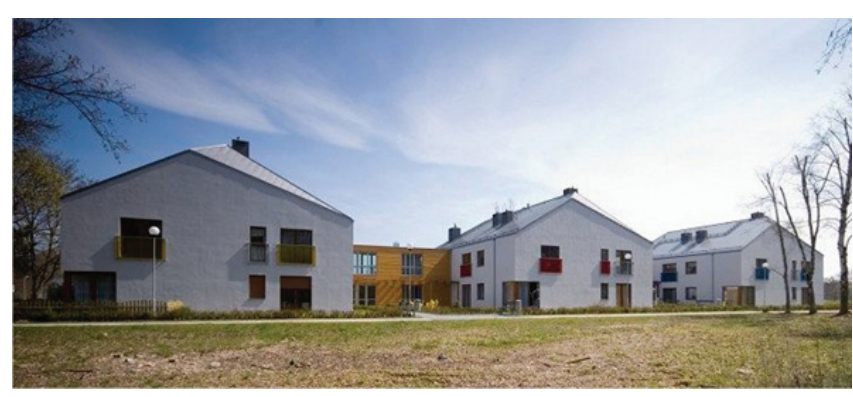

An important role in the investment was played by the "Nie Sami" Housing Aid Programme. The design received the first award in the category of residential buildings in the $20^{\text {th }}(2009)$ edition of the National "Construction of the Year"

Fig. 10. View of one of the segments consisting of three buildings and links between them Source: http://www.bryla.pl/bryla/56,85301,10707292,Architecture_dla_seniora_First_taki_budynek_w.html

\footnotetext{
${ }^{16}$ Prepared on the basis of: J. Dąbrowska, 2014, Zespót segmentów dla osób starszych w Stargardzie Szczecińskim, "Nie Sami"- Program mieszkaniowy dla osób starszych, Warszawa (available on the internet: http://fta.pl/wra/sites/default/files/upload/wraiii_jadwiga_dabrowska.pdf) (accessed on 18.08.2018) http://www.gs24.pl/wiadomosci/stargard/ art/5338386,osiedle-lotnisko-dla-seniorow-mozna-juz-tu-zamieszkac,id,t.html (accessed on 18.08.2018) http://www. bryla.pl/bryla/56,85301,10707292,Architektura_dla_seniora_Pierwszy_taki_budynek_w.html (accessed on 18.08.2018) TBS, 2012, Program operacyjny "Nie Sami"- Program mieszkaniowy dla osób starszych, Program Pomocy Mieszkaniowej, Stargard Szczecińsk (available on the internet: http://www.potrzebnydom.stargard.pl/dokumenty/programy/niesami/1_opis_programu\%20_nie_sami.pdf) (accessed on 18.08.2018).
} 
Competition. ${ }^{17}$ Residents did not take part in the participatory process. The first segments were completed in 2011 but the construction was completed in 2016. Currently, the residents are aged 55+. The type of construction consists of 4 complexes of 2-storey buildings connected by passages. The buildings are located on the outskirts of the city, $8 \mathrm{~km}$ from Stargard Szczeciński city centre. The investment consists of 94 flats, including residential units for disabled people (flats adapted to people with motor dysfunction, following the rules of assisted living). A medical caretaker is on duty 5 days a week and medical consultations are conducted in the apartment of a given person. A radio warning system is available in the area - in case of a life-threatening situation, the person on duty receives an immediate report of the accident.

\section{Senior Apartments, Wiazowna municipality}

Senior Apartments (Majdan, Wiązowna municipality) located in the Mazovia region is another Polish example of such an investment. ${ }^{18}$ It was completed in 2016 and is an example of a housing estate for seniors, which was designed by Archimed studio. The MEDI-system and Senior Apartments companies were the initiators of this project.

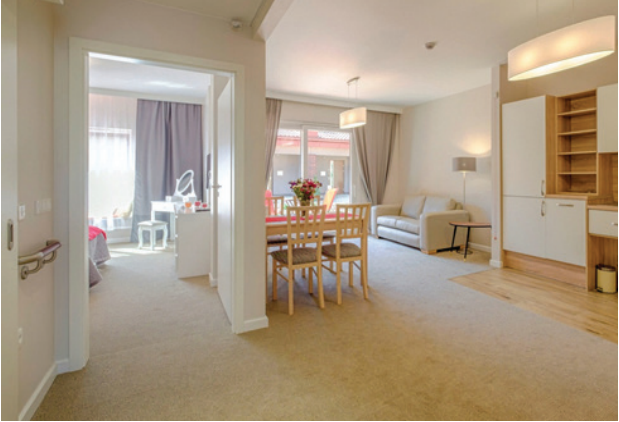

Fig. 12. View of a living room and kitchen

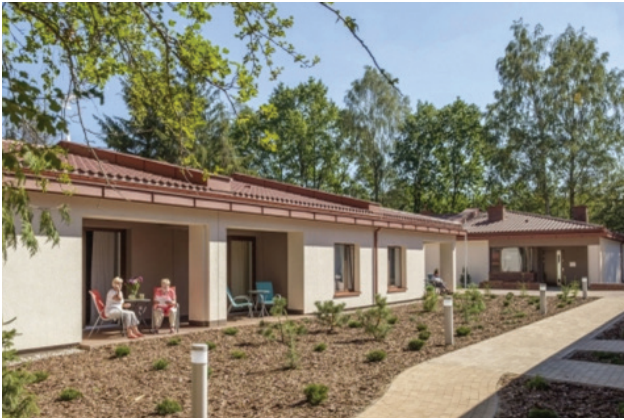

Fig. 11. View of single-storey houses in the form of apartments

Source: http://eurobuildcee.com/?page=news\&id=25372 (accessed on 23.08.2018)

The residents are aged 55+, active and independent, but also periodically or permanently in need of a care. The complex consists of 18 single-storey houses which implement the idea of assisted living. A medical team and auxiliary staff provide the required care - a large round-the-clock medical centre is located in the close vicinity, the apartments are equipped with motion and fall sensors that can alert the medical staff.

\footnotetext{
${ }^{17}$ The competition was organized by the Polish Association of Civil Engineers and Technicians in cooperation with the Ministry of Infrastructure and the Central Office of Construction Supervision.

18 Prepared on the basis of: http://www.rynekseniora.pl/inwestycje/107/powstaja_pierwsze_w_polsce_apartamenty_dla_starszych_w_formule_quot_assisted_living_quot_zobacz_wizualizacje,5158.html (accessed on 25.07.2018) http://www.propertydesign.pl/architektura/104/oto_supernowoczesne_osiedle_dla_seniorow,9146.html (accessed on 25.07.2018). http://archimed.pl/projekty/view/osiedle-senior-apartments-w-majdanie--gmina-wiazowna (accessed on 25.07.2018).
} 
The examples discussed above can be divided into two basic categories: from Poland (2) and other countries (2). This allows for a confrontation of different approaches to the construction of a place of residence. Not only in terms of typology but also of cultural significance, context of immediate surroundings, approach to the design process and possible engagement of residents. The results of the comparison are presented in Table 2.

Table 2. Comparative comparison of selected examples

\begin{tabular}{|c|c|c|c|c|}
\hline $\begin{array}{l}\text { Characteristics } \\
\text { of the facility }\end{array}$ & $\begin{array}{c}\text { Glacier Circle } \\
\text { USA }\end{array}$ & $\begin{array}{l}\text { Older Women's } \\
\text { Cohousing UK }\end{array}$ & $\begin{array}{c}\text { Senior citizens' } \\
\text { housing estate } \\
\text { Stargard Szczeciński, }\end{array}$ & $\begin{array}{l}\text { Senior Apartments } \\
\text { Majdan near Warsaw }\end{array}$ \\
\hline $\begin{array}{c}\text { Date } \\
\text { of creation }\end{array}$ & 2006 & 2016 & $2011(2016)$ & 2016 \\
\hline Location & Suburban areas & City centre & Suburban areas & Suburban areas \\
\hline $\begin{array}{l}\text { Form } \\
\text { of residence }\end{array}$ & Senior Cohousing & $\begin{array}{l}\text { Senior Cohousing } \\
\text { for women }\end{array}$ & $\begin{array}{l}\text { Senior citizens' } \\
\text { housing estate }\end{array}$ & $\begin{array}{l}\text { Senior citizens' } \\
\text { housing estate }\end{array}$ \\
\hline $\begin{array}{c}\text { Type } \\
\text { of buildings }\end{array}$ & $\begin{array}{l}\text { Newly designed, } \\
\text { detached buildings }\end{array}$ & $\begin{array}{l}\text { Newly designed, } \\
\text { single block }\end{array}$ & $\begin{array}{l}\text { Newly designed, } \\
4 \text { building units }\end{array}$ & $\begin{array}{l}\text { Newly designed, } \\
\text { detached houses }\end{array}$ \\
\hline $\begin{array}{l}\text { Number } \\
\text { of dwellings }\end{array}$ & $\begin{array}{c}8 \text { buildings, } \\
3 \text { types } \\
\text { of apartment sizes }\end{array}$ & $\begin{array}{c}1 \text { building, } \\
25 \text { apartments }\end{array}$ & $\begin{array}{l}4 \text { buildings, } \\
94 \text { apartments }\end{array}$ & $\begin{array}{c}18 \text { single-storey } \\
\text { apartments }\end{array}$ \\
\hline $\begin{array}{c}\text { Participatory } \\
\text { process }\end{array}$ & Yes & Yes & No & No \\
\hline Residents & $\begin{array}{l}\text { Age: } 74-92 \text { years } \\
\text { (average: } 80 \text { ) }\end{array}$ & $\begin{array}{c}\text { People } 50+ \\
\text { (women), } \\
\text { Age: } 50-80 \text { years }\end{array}$ & People 55+ & People 55+ \\
\hline Medical care & $\begin{array}{l}\text { A hired caretaker, } \\
\text { apartments } \\
\text { for caretakers } \\
\text { in the common } \\
\text { room/house }\end{array}$ & $\begin{array}{c}\text { A possibility of } \\
\text { creating } \\
\text { a separate room for } \\
\text { a caretaker in the flats }\end{array}$ & $\begin{array}{l}\text { A caretaker is available } \\
5 \text { days/week, } \\
\text { consultations } \\
\text { with a physician on } \\
\text { demand }\end{array}$ & $\begin{array}{c}\text { A medical team } \\
\text { and a 24-hour } \\
\text { medical centre } \\
\text { in the neighbourhood }\end{array}$ \\
\hline
\end{tabular}

Source: own elaboration

The main feature distinguishing examples from Poland and the world is the fact that Polish projects are residential estates for seniors rather than typical senior cohousing. The age of residents is similar, though. The main difference is the type of housing development on a plot - from individual buildings constructed as segments (Glacier Circle, the housing estate in Stargard Szczeciński), through houses of apartment standard (Senior Apartments), to solutions such as the building of a single block $(\mathrm{OWCH})$. An important element that should be emphasized is the participation of residents in the planning of the investments from the very beginning - this feature was present in only foreign examples. Due to the nature of buildings dedicated to older people, the access to permanent or temporary medical care is of utmost importance. In Glacier Circle a caretaker was employed; another solution was 
implemented in $\mathrm{OWCH}$, where it is possible to create a room for a caretaker. The housing estate in Stargard Szczeciński offers its residents consultations with a physician and the presence of a caretaker during the week. In the case of the Senior Apartments housing estate, the medical centre is located in the close vicinity. The housing estate in Stargard Szczeciński and the complex of single-storey apartments in Majdan implement the idea of assisted living. Thanks to this, the apartments are equipped with modern accessories and sensors which immediately send information to the medical staff in case of an accident.

The development layout of cohousing meets the highest standards necessary for the well-being of older people through its ideas, shaping of the architecture and supplementary elements. It provides a sense of security, shows the value of community and eliminates the feeling of loneliness. On the other hand, it allows the residents to maintain their privacy. The very process of determining needs in the case of cohousing is a part of a multistage process of participation by specialists and its future users who, through mutual cooperation, define their expectations, strengthen ties and set their goals clearly, which results in the construction of a new housing estate. The participatory process becomes the foundation that binds the whole investment together. When it is well executed, it ensures the success of the whole community and results in a well-designed building and spatial development that meets the expectations of the residents.

\section{Conclusion}

The aim of this paper was to find answers to the questions posed in the introduction. One of the key issues is identification of the needs of future users, as well as the multidimensional effects of the ageing process. Taking them into account allows for the creation of a functional and spatial programme that fully meets the residents' expectations. The feeling of loneliness, rejection and isolation are a good motivation to start considering the typology of a housing estate that would be close to the ideal. The development layout of cohousing, through its ideas, shaping of the architecture and supplementary elements, meets the highest criteria necessary for the well-being of the older people. It provides a sense of security and the required medical care, shows the value of community, eliminates the feeling of loneliness, and, at the same time, allows privacy to be maintained. The very process of determining needs in the case of cohousing is a part of a multistage process of participation by specialists and its future users, who, through mutual cooperation, define their expectations, strengthen ties and set their goals clearly, which results in the construction of a new housing estate. Cooperation with future residents characterises only the examples of buildings from around the world, but is missing in Poland.

Senior cohousing is a response to the contemporary demographic processes - the ageing of the society (singularization, feminization, etc.). The momentum of modern life does not allow for these threats to be noticed in the immediate neighbourhood and effectively counteract them. The development layout of cohousing provides a sense of comfort thanks to zoning, motivates people to spend time together, to share knowledge and experiences, as 
well as to rest together. A community managed by its inhabitants, sometimes with a little help from the outside, provides a greater sense of responsibility and ownership. The same is true for making decisions about the community during regular meetings of all residents, which should be based on mutual understanding, respect and making decisions that are good for everyone.

Cohousing development can take on different forms - from single-structure buildings to an arrangement of functions distributed among several spaces. The projects that were developed and discussed in the case studies presented residential buildings as compact city blocks or apartments within detached houses. The type of buildings is not so important if the zones pass smoothly one into another: private - semi-public - public; and together they form a coherent and harmonious whole that facilitates everyday functioning. Such actions should result in a well-functioning, collision-free and efficient housing estate, with zones facilitating rest in solitude, places to meet with closest acquaintances, and public spaces that are accessible to all. The models that contribute the most to creating a community are those that provide a common space in the middle of the housing project. It is visible from most flats and it houses a common meeting room. Staircases that are directed towards the inside of such space generate traffic, which enables natural interaction between neighbours. The architectural and urban elements in senior cohousing buildings should facilitate mobility, as the residents are usually people with various dysfunctions associated with the ageing process. Both easy orientation and clear and comfortable communication are some of the key aspects of good buildings dedicated to seniors. Meeting places, which are adequately shaded and contain elements of small architecture facilitating leisure, should provide an opportunity to meet with those closest to them in the surrounding greenery. Places of common activities such as an outdoor gym or minigolf should ensure safety and provide a varied choice of functions. Private resting areas need to be separated from public areas but should remain connected to them by semi-public passages.

Does senior cohousing have a chance to emerge on a large scale in Poland and replace the institutional and paternalistic methods of caring for the older people? This type of building development, which is still a niche in the Polish construction industry, should be treated as an alternative to the current old people's homes and nursing homes. People living in cohousing could experience a more positive dimension of old age, deprived of the sense of alienation or inferiority to others. They would feel that they are needed and their advanced age and knowledge is an invaluable source of experience which should be utilised. 


\section{References}

Benek I., Szewczenko A., 2015 , Ergonomia w projektowaniu obiektów z funkcja opieki dla osób starszych, Wydział Architektury, Zeszyty Naukowe Małopolskiej Wyższej Szkoły Ekonomicznej w Tarnowie, 27, 2-3, p. 81-82.

Błędowski P. et al., 2012, Raport na temat sytuacji osób starszych w Polsce, Instytut Pracy i Spraw Socjalnych, Warszawa.

Durrett Ch., 2009, The Senior Cohousing Handbook. A Community Approach to Independent Living, New Society Publishers.

Główny Urząd Statystyczny, 2014, Prognoza ludności na lata 2014-2050, Warszawa, p. 77.

Główny Urząd Statystyczny, 2015, Podstawowe informacje o rozwoju demograficznym Polski do 2014 roku, Warszawa, p. 13-15.

Niezabitowska E., 2014, Metody i techniki badawcze w architekturze, Wydawnictwo Politechniki Śląskiej, Gliwice.

PetyniakR., 2015, Uniwersytet Trzeciego Wieku, instytucjąedukacyjna i wspierajaca osoby wstarszym wieku. Na przykładzie opinii uczestników Uniwersytetu Trzeciego Wieku przy Uniwersytecie Rzeszowskim. Praca magisterska. Uniwersytet Rzeszowski, Wydział Pedagogiczny, Rzeszów.

\section{Websites used}

http://archimed.pl/projekty/view/osiedle-senior-apartments-w-majdanie--gmina-wiazowna (accessed on 25.07.2018)

http://www.bryla.pl/bryla/56,85301,10707292,Architektura_dla_seniora_Pierwszy_taki_ budynek_w.html (accessed on 18.08.2018)

http://encyklopedia.pwn.pl/haslo/starzenie-sie;3979189.html (accessed on 19.06.2018)

http://fta.pl/wra/sites/default/files/upload/wraiii_jadwiga_dabrowska.pdf) (accessed on 18.08.2018)

http://www.gs24.pl/wiadomosci/stargard/art/5338386,osiedle-lotnisko-dla-seniorowmozna-juz-tu-zamieszkac,id,t.html (accessed on 18.08.2018)

https://www.jrf.org.uk/sites/default/files/jrf/migrated/files/senior-cohousing-communitiesfull.pdf) (accessed on 21.08.2018)

http://kigs.org.pl/projekty/gospodarka-senioralna/ (accessed on 19.06.2018) 


\section{SENIOR COHOUSING IN THE CONTEXT OF AN AGEING SOCIETY \\ Małgorzata Kampka}

http://mateuszgrzesiak.natemat.pl/122459,21-roznic-pokoleniowych-miedzy-baby-boomers$\mathrm{x}-\mathrm{i}-\mathrm{y}$ (accessed on 19.06.2018)

http://www.potrzebnydom.stargard.pl/dokumenty/programy/niesami/1_opis programu\%20_nie_sami.pdf) (accessed on 18.08.2018)

http://www.propertydesign.pl/architektura/104/oto_supernowoczesne_osiedle_dla_ seniorow,9146.html (accessed on 25.07.2018)

http://www.rynekseniora.pl/inwestycje/107/powstaja_pierwsze_w_polsce_apartamenty_ dla_starszych_w_formule_quot_assisted_living_quot_zobacz_wizualizacje,5158.html (accessed on 25.07.2018)

http://sarp.warszawa.pl/wordpress/wp-content/uploads/2015/11/opis-WMS.pdf (accessed on 27.06.2018)

http://stat.gov.pl/obszary-tematyczne/ludnosc/ludnosc/podstawowe-informacje-o-rozwojudemograficznym-polski-do-2014-roku,12,5.html) (accessed on 24.06.2018) 


\section{Cohousing senioralny w kontekście starzejącego się społeczeństwa}

\section{STRESZCZENIE}

Procesy demograficzne XXI w., a szczególnie wszystkie aspekty starości wymagają podjęcia dyskusji na temat potrzeb starzejącego się społeczeństwa. W konsekwencji powinny prowadzić do wypracowania modelowych rozwiązań urbanistycznych i architektonicznych dla osób starszych, wzorowanych na przykładach cohousingu senioralnego. Pod uwagę należy wziąć również sam proces starzenia się, który dotyka osoby starsze na wielu płaszczyznach i wpływa na ich funkcjonowanie w społeczeństwie.

Zamierzeniem niniejszej pracy jest uzyskanie odpowiedzi na postawione pytania badawcze, dotyczące elementów architektonicznych oraz urbanistycznych cohousingu senioralnego oraz ocena, czy ten typ zabudowy jest dobra odpowiedzią na procesy demograficzne XXI w. związane z procesem starzenia się. Dodatkowo celem jest wskazanie różnic między budownictwem przeznaczonym dla seniorów w kraju i za granicą.

Przyjęta metodologia badań na zasadzie studium przypadku, analizy literatury oraz komparatystyki pomogła porównać przykłady z kraju i ze świata, aby przybliżyć rozwiązanie, które wychodzi naprzeciw wyzwaniom współczesnej demografii - jest to forma zamieszkania typu cohousing, której fundamentalnym założeniem jest życie we wspólnocie, przy jednoczesnym zachowaniu prywatności i samodzielności.

W studium przypadku zwrócono uwagę na kilka wytycznych takich jak: lokalizacja, średnia wieku mieszkańców, udział w procesie partycypacyjnym, dostęp do opieki medycznej, program funkcjonalno-przestrzenny obiektów. Potencjał idei zabudowy przeznaczonej dla osób starszych jest szeroko rozpowszechniony na świecie, natomiast w Polsce nadal pozostaje niewykorzystany. Cohousing senioralny wpisuje się w model zabudowy ułatwiającej ludziom starszym codzienne funkcjonowanie. Przebywanie we wspólnocie zachęca do dzielenia się doświadczeniami, problemami lub spędzania czasu wolnego w otoczeniu znajomych i budowania cennych relacji. Ten rodzaj zabudowy powinien być traktowany jako alternatywa dla domów starców i domów opieki. Przyjęte rozwiązania zabudowy senioralnej będą dotyczyły teraźniejszości, lecz również przyszłych pokoleń

Słowa kluczowe: cohousing senioralny, starzenie się, wspólnota

MSc Eng. Arch. Małgorzata Kampka - architect and graphic designer, interior architect in the BAGUA Architecture Studio, designs interiors of single-family houses and flats, a member of the Laboratory of Architecture $60+(L A B 60+)$, interested in the subject of senior architecture; contact to the author:Mglista 10 B/7, 44-207 Rybnik, e-mail:makashari@gmail.com

mgr inż. arch. Małgorzata Kampka - architekt oraz grafik, specjalizuje się tematyce architektury senioralnej, architekt wnętrz w Pracowni Architektury BAGUA, projektuje wnętrza domów jednorodzinnych i mieszkań, członkini Laboratorium Architektury 60+ (LAB 60+); kontakt do autora: ul. Mglista 10 B/7, 44-207 Rybnik, e-mail:makashari@gmail.com 